\title{
Multiple Eph Receptors and B-Class Ephrins Regulate Midline Crossing of Corpus Callosum Fibers in the Developing Mouse Forebrain
}

\author{
Shannon W. Mendes, ${ }^{1}$ Mark Henkemeyer, ${ }^{2}$ and Daniel J. Liebl ${ }^{1,3}$ \\ ${ }^{1}$ Neuroscience Program, University of Miami Miller School of Medicine, Miami, Florida 33136, ${ }^{2}$ Center for Developmental Biology and Kent Waldrep \\ Foundation Center for Basic Research on Nerve Growth and Regeneration, University of Texas Southwestern Medical Center, Dallas, Texas 75390, and ${ }^{3}$ The \\ Miami Project to Cure Paralysis and Department of Neurosurgery, University of Miami School of Medicine, Miami, Florida 33136
}

\begin{abstract}
Agenesis of the corpus callosum (CC) is a rare birth defect that occurs in isolated conditions and in combination with other developmental cerebral abnormalities. Recent identification of families of growth and guidance molecules has generated interest in the mechanisms that regulate callosal growth. One family, ephrins and Eph receptors, has been implicated in mediating midline pathfinding decisions; however, the complexity of these interactions has yet to be unraveled. Our studies shed light on which B-class ephrins and Eph receptors function to regulate $\mathrm{CC}$ midline growth and how these molecules interact with important guideposts during development. We show that multiple Eph receptors (B1, B2, B3, and A4) and B-class ephrins (B1, B2, and B3) are present and function in developing forebrain callosal fibers based on both spatial and temporal expression patterns and analysis of gene-targeted knock-out mice. Defects are most pronounced in the combination double knock-out mice, suggesting that compensatory mechanisms exist for several of these family members. Furthermore, these CC defects range from mild hypoplasia to complete agenesis and Probst's bundle formation. Further analysis revealed that Probst's bundle formation may reflect aberrant glial formations and/or altered sensitivity of CC axons to other guidance cues. Our results support a significant role for ephrins and Eph receptors in CC development and may provide insight to possible mechanisms involved in axon midline crossing and human disorder.
\end{abstract}

Key words: ephrins; Eph receptors; corpus callosum; midline guidance; mouse development; glial wedge

\section{Introduction}

Developing neurons project their axons over significant distances with remarkable accuracy (Tessier-Lavigne and Goodman, 1996). This is accomplished in part by the response of the growth cone to a variety of repulsive and attractive cues at specific guideposts throughout its growth pathway (Dickson, 2002; Huber et al., 2003). One important choice point for commissural axons is the CNS midline, where several families of guidance molecules function to direct or prevent midline crossing. Recently, ephrins and Eph receptors have also been implicated in commissural axon guidance (Kaprielian et al., 2001).

Eph receptors are receptor tyrosine kinases that function together with their ephrin ligands in a number of developmental processes (Wilkinson, 2001; Kullander and Klein, 2002). These functions are achieved through cell-cell contact, because both

Received July 29, 2005; revised Nov. 11, 2005; accepted Dec. 2, 2005

This work was funded by The Miami Project to Cure Paralysis (D.J.L.), National Institutes of Health (NIH)-National Institute of Neurological Disorders and Stroke Grant NS30291 (D.J.L.), The American Psychological Association Fellowship/Diversity Program in Neuroscience (S.W.M.), Lois Pope Life Fellowship (S.W.M.), and NIH-National Institute of Mental Health Grant MH66332 (M.H.). We thank Jannis Brea, Lissette Garcia, and Alma Rodenas-Ruano for technical assistance and Dr. John Bixby for helpful comments on this manuscript. We also thank Dr. Patrick Charnay for his gracious gift of the EphA4 knock-out mice.

Correspondence should be addressed to Dr. Daniel J. Liebl, Assistant Professor, The Miami Project to Cure Paralysis, The University of Miami, 1095 Northwest 14th Terrace, R-48, Miami, FL 33136. E-mail: dliebl@miami.edu. DOI:10.1523/JNEUROSCI.3162-05.2006

Copyright $\odot 2006$ Society for Neuroscience $\quad$ 0270-6474/06/260882-11\$15.00/0 receptor and ligand are membrane-bound molecules. B-class ephrins have the ability to interact with several B-class Eph receptors with varying degrees of specificity, whereas A-class ephrins interact with A-class Eph receptors. One exception is EphA4 receptor, which is known to interact with both A- and some B-class ephrins. Interactions between B-class ephrins and Eph receptors can generate bidirectional intracellular signals that in part lead to cytoskeletal changes (Klein, 2004).

Few studies have examined ephrins and Eph receptors in the more rostral midline regions of the CNS, and those few have focused mainly on the postnatal morphology of the anterior commissure (AC) and corpus callosum (CC) (Henkemeyer et al., 1996; Orioli et al., 1996). These studies have found EphB2 fusion protein and EphB3 mRNA expression in the CC during the development of this tract (Henkemeyer et al., 1996; Orioli et al., 1996), which occurs between embryonic day 15 (E15) and E18 in the mouse CNS (Rash and Richards, 2001). In addition, EphA receptors were also detected in CC fibers, suggesting a possible function for these molecules in CC development (Kudo et al., 2005). Analysis of EphB2 knock-out (EphB2 $\left.{ }^{K O}\right)$ and EphB3 ${ }^{K O}$ mice supported a role for Eph receptors in CC and AC midline pathfinding (Henkemeyer et al., 1996; Orioli et al., 1996). Other studies have shown that the deletion of the intracellular domain of EphA5 receptor results in callosal fibers failing to enter the commissure, a phenotype known as CC hypoplasia (Hu et al., 
2003). Although EphB2, EphB3, and EphA5 receptors have been implicated in CC development, the developmental expression and function of EphB1, EphA4, and B-class ephrins in the embryonic CC is relatively unknown.

In this study, we demonstrate that ephrins and Eph receptors are expressed in callosal fibers and strategic guideposts in the developing forebrain. This study also reveals multiple functional redundancies in the interactions between Eph receptors and ephrinB3 that may influence callosal development. The trajectory of CC fibers in the ephrin and Eph receptor knock-out mice reveals an important relationship between the residential glial cells and Probst's bundle formation and suggests that ephrins and Eph receptors not only regulate growth promoting functions and/or guidance signals but also the cellular organization of local guideposts.

\section{Materials and Methods}

Transgenic mice, breeding, and genotyping. EphB1 ${ }^{\mathrm{KO}}, \mathrm{EphB2}{ }^{\mathrm{KO}}$, EphB3 ${ }^{\text {KO }}, E p h B 2^{\text {LacZ }}, E p h A 4^{K O}$, ephrinB3 ${ }^{K O}$, ephrin2 $2^{\text {lacZ }}$, and ephrin3 ${ }^{\text {lacZ }} \mathrm{CD} 1$ mutant mice and genotyping methods have been described previously (Gale et al., 1996a; Henkemeyer et al., 1996; Orioli et al., 1996; Helmbacher et al., 2000; Yokoyama et al., 2001; Williams et al., 2003; Dravis et al., 2004). Using available single mutant mice, receptorreceptor double knock-out mice were generated, including $E p h B 1^{K O}$ / EphB2 $2^{K O}, E p h B 1^{K O} / E p h B 3^{K O}, \quad E p h B 1^{K O} / E p h A 4^{K O}, E p h B 2^{K O} /$ $E p h B 3^{K O}, E p h B 2^{\text {lacz }} / E p h B 3^{K O}$, and EphB3 ${ }^{K O} / E p h A 4^{K O}$. Additionally, receptor-ligand double mutants (ephrinB $3^{K O} / E p h B 1^{K O}$, ephrinB3 ${ }^{K O} /$ $E p h B 2^{K O}$, and ephrinB3 ${ }^{K O} / E p h A 4^{K O}$ ) were generated. Procedures related to animal use and care were approved by the University of Miami Animal Care and Use Committee.

Immunohistochemistry and imaging. Embryos of appropriate time points (E15, E16, E17, E18) were obtained from timed pregnant dams. The plug date was defined as E0, and the day of birth as postnatal day 1 (P1). On the appropriate embryonic time point, pregnant female mice were anesthetized and embryos were removed by caesarian section. After removal of embryos, the female mice were killed with a lethal injection of ketamine mixture. Brains were dissected and immersed in $4 \%$ paraformaldehyde (PFA) (Fisher Scientific, Boulder, CO) made up in $1 \times$ PBS for $1 \mathrm{~h}$. Brains were then cryoprotected in $25 \%$ sucrose overnight at $4^{\circ} \mathrm{C}$ and finally embedded in OCT (Tissue-Tek, Miles, Elkhart, IN). Cryosections were cut at $10 \mu \mathrm{m}$ and mounted on microslides, permeablized in 0.05\% Triton X-100 (Sigma, St. Louis, MO) for $20 \mathrm{~min}$, and immersed in $5 \%$ bovine serum albumin (BSA) (Fisher Scientific) blocking solution for $30 \mathrm{~min}$ at room temperature (RT). Antibodies specific for EphB1 (1:25; Santa Cruz Biotechnology, Santa Cruz, CA), EphB3 (1:25; R \& D Systems, Minneapolis, MN), EphA4 (1:100; R \& D Systems), and ephrinB1 (1:100; Santa Cruz Biotechnology) were diluted in 5\% BSA/0.1\% Triton $\mathrm{X}-100$ and allowed to incubate with sections for $1 \mathrm{~h}$ at RT followed by overnight at $4^{\circ} \mathrm{C}$. For single or colabeling, antibodies against Tag-1 (1: 100; Developmental Studies Hybridoma Bank, Iowa City, IA), GFAP (1:1000; DakoCytomation, Carpinteria, CA), $\beta$-galactosidase ( $\beta$-gal; 1:200), RC-1 or RC-2 (1:200; Developmental Studies Hybridoma Bank), GAP-43 (1:500), neurofilament (NF; 1:500; $145 \mathrm{kDa})$, and $\beta$-tubulinIII, (1:1000; Chemicon, Temecula, CA) were used. Sections were then washed three times for 5 min each in $1 \times$ PBS and then incubated with FITC and/or Texas Red-conjugated secondary antibodies (Invitrogen, San Diego, CA) for $1 \mathrm{~h}$ at RT. Sections were washed again in $1 \times$ PBS three times for $5 \mathrm{~min}$ each and coverslipped using an aqueous gel-mount (Biomeda, Foster City, CA). Sections for GFAP immunohistochemistry were embedded in $3 \%$ agarose (Invitrogen), sectioned at $75 \mu \mathrm{m}$, immersed in $0.1 \%$ Triton X-100 in $1 \times$ PBS, and transferred to $5 \%$ BSA for blocking. Sections were incubated free-floating in GFAP antibody (1: 3000; DakoCytomation) diluted in 5\% BSA/0.1\% Triton X-100 for $48 \mathrm{~h}$ at $4^{\circ} \mathrm{C}$. Sections were then incubated with anti-rabbit biotinylated secondary antibody (1:500; Vector Laboratories, Burlingame, CA) for $1 \mathrm{~h}$. Vectastain $\mathrm{ABC}$ reagent was then added for $1 \mathrm{~h}$ at $\mathrm{RT}$ followed by washes three times for $5 \mathrm{~min}$ each. Sections were then incubated in peroxidase substrate until the desired staining was achieved. Sections were rinsed in distilled water, mounted on microslides, dehydrated in alcohol washes (70, 80, 95, 100\%; two times for 5 min each), and finally coverslipped in Sub-X mounting media (Surgipath, Richmond, IL). Sections for fluorescent or nonfluorescent immunostaining were imaged using an inverted microscope (Axioscope; Zeiss, Oberkochen, Germany).

$\beta$-Galactosidase histochemistry. Tissue was prepared and cryosectioned at $10 \mu \mathrm{m}$ as described previously. EphB2, ephrinB2, and ephrinB3 were detected using dated embryos homozygous for the $\beta$-gal gene. Sections were incubated with X-gal (Vectra) staining solution (5 mM Kferri/ Kferro cyanide, $2 \mathrm{~mm} \mathrm{MgCl}$, $1 \mathrm{mg} / \mathrm{ml} \mathrm{X-gal,} 1 \times \mathrm{PBS}$ ) (Sigma) for $1-2 \mathrm{~h}$ at RT, then washed in $1 \times$ PBS three times for $5 \mathrm{~min}$, and finally dehydrated in an ascending alcohol series (70, 80, 95, and 100\%). Sections were coverslipped with Sub-X mounting media (Fisher Scientific) and imaged in bright field.

Cresyl violet staining and histological analysis of the corpus callosum. Using time pregnant females, embryonic brains from appropriate time periods were obtained, sectioned, and mounted as described previously under immunohistochemical techniques. Sections were then stained in cresyl violet staining solution $(0.1 \%$ cresyl violet acetate, 1 m sodium acetate, $1 \mathrm{~m}$ glacial acidic acid, 95\% ethanol) (Sigma) for $1 \mathrm{~min}$ followed by rinses in alcohol solutions (50,70,90, 95, and 100\% and xylene) and finally imaged in bright field. Sample numbers are indicated for each genotype examined.

Quantification of corpus callosum thickness. Sections from P1 mice were obtained as described previously for cryosection immunostaining. Sections $(30 \mu \mathrm{m})$ were stained with anti- $\beta$-tubulinIII (1:500; Covance, Princeton, NY) antisera diluted in 5\% BSA/0.1\% Triton X-100 for $1 \mathrm{~h}$ at RT followed by overnight at $4^{\circ} \mathrm{C}$. On the following day, sections were rinsed three times for 5 min each in $1 \times \mathrm{PBS}$ and the incubated with Texas Red (594 nm)-conjugated secondary antibody (1:250; Jackson ImmunoResearch, West Grove, PA). Sections were rinsed three times for $5 \mathrm{~min}$ in $1 \times$ PBS, imaged, and photographed using a fluorescent microscope. The thickness of the CC (at the level of the hippocampal commissure) was measured using Zeiss interactive measurement software. At least five coronal sections for each genotype were quantified using this software, and statistical significance was determined using one-way ANOVA with Bonferroni's correction in Prism 3.02 (GraphPad Software, San Diego, CA) statistical software.

1,1'-Dioctadecyl-3,3,3',3'-tetramethylindocarbocyanine perchlorate tract tracing or 3,3'-dioctadecyloxacarbocyanine perchlorate tract tracing. P1 mice $(n=3-5)$ were anesthetized on ice, and a small area of brain was exposed. For tracing of the corpus callosum, a 10\% 1,1'-dioctadecyl$3,3,3^{\prime}, 3^{\prime}$-tetramethylindocarbocyanine perchlorate (DiI; D-282) or 3,3'dioctadecyloxacarbocyanine perchlorate (DiO; D-275) (Invitrogen) solution made up in $\mathrm{N}$-N-dimethylformamide (Sigma) was injected into the cingulate cortex of the anesthetized pups. For all tracing, dye solution $(0.3 \mu \mathrm{l})$ was injected into one hemisphere using a Hamilton syringe, and pups were allowed to survive for $6 \mathrm{~h}$. After this incubation period, pups were anesthetized and perfused with $4 \% \mathrm{PFA}$, and brains were postfixed for $24 \mathrm{~h}$ at $4^{\circ} \mathrm{C}$. Brains were then embedded in 3\% agarose, vibratome sectioned at $100 \mu \mathrm{m}$, immunostained with anti-GFAP antibody, and photographed under rhodamine (DiI) illumination. Some images were obtained using a laser scanning confocal microscope (Zeiss LSM 510), and stacked images were created using Zeiss LSM image browser.

Glial wedge and cortical dissociated cultures. Timed pregnant female wild-type (WT) and ephrinB $3^{\mathrm{KO}}$ or EphB1 ${ }^{\mathrm{KO}}$ transgenic CD1 mice were anesthetized with ketamine mixture, and E17 pups were removed from the abdomen. Pups were anesthetized on ice, and brains were dissected and placed in ice-cold L-15 media (Invitrogen). Brains were then embedded in 3\% low melting point agar (SeaPlaque; Cambrex BioScience Rockland, Rockland, ME) and sectioned at $300 \mu \mathrm{m}$, and finally cortical and glial wedge (GW) tissue was dissected from coronally sectioned brains. The brain tissue was placed in $0.05 \%$ trypsin-EDTA (Invitrogen) and incubated for $2 \mathrm{~min}$, and trypsin was then neutralized with serumcontaining media. The tissue was triturated 15 times, centrifuged at 6500 $\mathrm{rpm}$, and the supernatant was aspirated. The remaining pellet was resuspended in growth media [minimum essential media, 10\% heatinactivated horse serum, $2 \mathrm{~mm}$ L-glutamine, $0.5 \%$ glucose, and $1 \times$ peni- 
cillin-streptomycin (Invitrogen)]. Twentyfour well tissue culture dishes were precoated with poly-L-lysine (Sigma), and then feeder layers of WT cortical or glial wedge tissue were applied at $5 \times 10^{5}$ cells per well and incubated at $5 \% \mathrm{CO}_{2}$ and $37^{\circ} \mathrm{C}$ for $24 \mathrm{~h}$. On the following day, $4 \times 10^{6}$ cortical cells were transfected with a green fluorescent protein (GFP) reporter using nucleotransfection system (Amaxa, Gaithersburg, MD), and a low density of cells were plated with either pre-established cortical or glial wedge feeder layers. Cultures were incubated for $3 \mathrm{~d}$, and images were taken of neurites. Neurite length was quantitated with Zeiss interactive measurement tools, and comparisons were made using Student's $t$ test (Prism 3.02). Only axons greater then two times the diameter of the soma are counted to provide analysis of healthy cells. Some cultures were fixed and immunostained using anti-GFP (1: 1000; Chemicon), Tau-1 (1:2000; Zymed, San Francisco, CA), and RC-2 (1:200; Developmental Studies Hybridoma). Experiments were performed three times in triplicate.

Cortical neuron cultures on ephrin-Fc substrates. Embryonic cortical neurons were obtained as described above. Tissue-culturegrade coverslips were incubated with poly-Dlysine (Sigma) overnight at $37^{\circ} \mathrm{C}$ and then washed with $1 \times$ PBS (Invitrogen). Ephrin-Fc proteins [ephrinB1-Fc, ephrinB2-Fc, and ephrinB3-Fc (R \& D Systems) and Fc fragment (Jackson ImmunoResearch)] were diluted in $1 \times$ PBS at final concentrations of 6.0 or 0.6 $\mu \mathrm{g} / \mathrm{ml}$. Coverslips were incubated for $2 \mathrm{~h}$ with ephrinB-Fc proteins at $37^{\circ} \mathrm{C}$ and then washed with $1 \times$ PBS similar to as described previously (Birgbauer et al., 2001). After preparation of coverslips, cortical neurons were cultured on coverslips at low densities. Cortical neurons were incubated at $37^{\circ} \mathrm{C}$ for $3 \mathrm{~d}$ and then fixed and immunostained with $\beta$-tubulinIII. Images were obtained and neurites (longer than twice the diameter of the cell body) were measured using Zeiss software. Comparisons were made using one-way ANOVA with Bonferroni's correction. Experiments were performed three times in triplicate.

\section{Results}

\section{Forebrain development in CD1 mice}

To begin examining the role of ephrins and Eph receptor in the developing forebrain, we first evaluated the developmental timing of CC growth and appearance of forebrain guideposts in CD1 WT mice. Immunolabeling with anti- $\beta$-tubulinIII, a general cytoskeletal marker for all axons, showed that at E15, few axons had crossed the midline, whereas by E17, a large population of axons had extended into the opposite hemisphere (Fig. $1 a-c, g$ ). This timing was confirmed by tracing the CC axons with the lipophilic tracer DiI where fibers projected across the midline between E15 and E16 in development (Fig. $1 a^{\prime}, b^{\prime}$ ). Another prominent axonal pathway present in the developing forebrain is the perforating pathway (Pfp), which is mainly formed by neurons in the diagonal band of Broca/medial septum (DBMS) and cingulate cortex that extend axons dorsally and ventrally, respectively. At the embryonic midline, axons of the Pfp project ipsilaterally around the same developmental time point as CC fibers and predominantly immunoreact with anti-NF (145 kDa) antibodies (Fig. $1 d-f, h)$. Three glial populations that have been described to function in midline guidance of CC fibers are born around E14 and have matured by E18, a time point when most or all CC fibers have crossed the midline (Rash and Richards, 2001; Shu et al., 2003b)
(Fig. 1i). As reported previously, immunolabeling of E18 forebrain tissue with anti-GFAP revealed these three glial populations, which include the indusium griseum (Ig), GW, and midline zipper glia (mzg) (Shu et al., 2003b). These studies demonstrate that the developing CC and midline structures in CD1 mice are similar to those described previously for C57BL/6 mice (Silver et al., 1993; Rash and Richards, 2001; Shu et al., 2003b).

\section{Expression of ephrins in the developing forebrain}

To determine whether ephrins are important for formation of the CC, we first examined whether B-class ephrins are expressed in the commissure or surrounding areas during development. We found that all three B-class ephrins are expressed in the forebrain at E15, a time point at which callosal fibers are approaching the midline and pioneer fibers begin crossing into the contralateral hemisphere. At E15, ephrinB1 was expressed in the differentiating fields of the frontal neocortex, cingulate cortex, corticoseptal boundary, and Ig, as well as regions that contain cortical, callosal, and Pfp fiber projections (Fig. 2a,b). At this stage, the GW continues to mature and callosal fibers have not yet projected to the region of midline crossing. At E16, ephrinB1 expression was more restricted in the frontal cortex to structures such as the CC, Pfp, Ig, and septum, as well as a discrete region of the cortex and superior portion of the lateral ventricle (Fig. $2 c$ ). This discrete region of the subventricular zone and cortex is thought to represent projecting radial glia (Shu et al., 2003b; Williams et al., 2003), which was confirmed by immunohistochemistry with the radial glia marker anti-RC1 (Fig. $2 d$ ). This RC-1 expression pattern mimics ephrinB1 immunostaining in the region of the dorsolateral ventricle $(\mathrm{dLv})$ but disappears by E17 in development (data not shown). Colabeling ephrinB1 with $\beta$-tubulinIII 

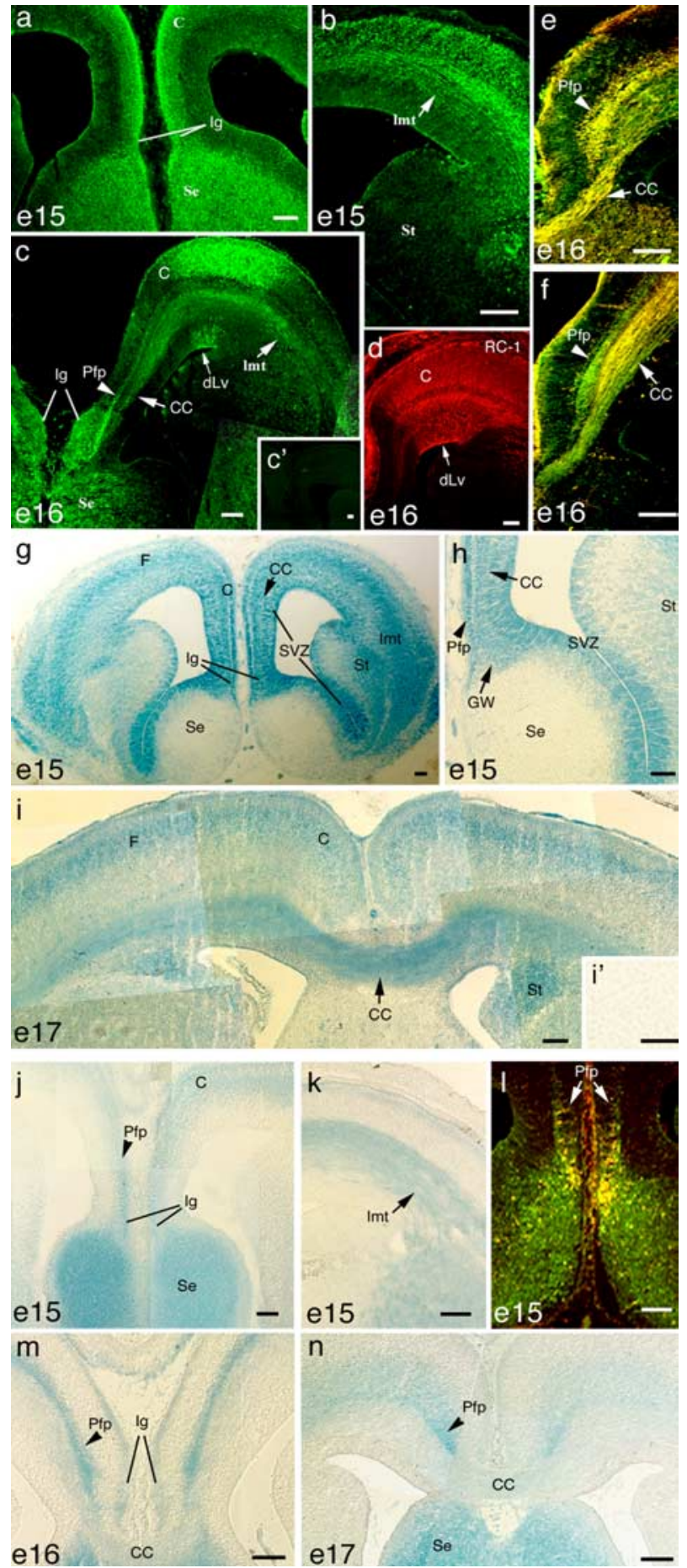

Figure 2. B-class ephrins are expressed in the developing forebrain. At E15, ephrinB1 is expressed in forebrain regions corresponding to the cortex (C), septum (Se), Ig, and lateromedial tract (Imt) $(\boldsymbol{a}, \boldsymbol{b})$, whereas at E16, ephrinB1 is also expressed in regions that include the $C C$, Pfp, $\lg , C$, Se, and unique regions of the $\mathrm{dLv}(\boldsymbol{c})$. $\boldsymbol{d}, \mathrm{RC}-1$ is also expressed in the $\mathrm{dLv}$, similar to ephrinB1 expression. , At E16, ephrinB1 (green) colabels with $\beta$-tubulinlll (red) in both the CC and Pfp fibers (yellow). $f$, EphrinB1 (green) colabels with Tag-1 (red) in CC (yellow) and not Pfp fibers. EphrinB2 expression was visualized by examining $\beta$-gal expression in the ephrinB2 ${ }^{\text {Lacz }}$ mice. $\boldsymbol{g}, \boldsymbol{h}$, AtE15, ephrinB2 expression is localized to regions corresponding to the C, CC, GW, Ig, Pfp, striatum (St), and subventricular zone (SVZ) but absent in the Se. F, Forebrain. $\boldsymbol{j}, \boldsymbol{k}$, By E17, ephrinB2 expression localized to the C, CC, GW, and St (i). EphrinB3 expression was visualized using ephrinB3 ${ }^{\text {lacZ }}$ mice. At E15, ephrinB3 was expressed in the Pfp, Ig, Se, and Imt. $I$, Anti- $\beta$ galactosidase antibodies (green) colabeled with GFAP (red) in the lg (yellow). $\boldsymbol{m}, \boldsymbol{n}$, At E16 and E17, ephrinB3 expression is maintained in the Pfp, Ig, and Se, but little to no expression is observed in the $\mathrm{CC}^{\prime} \boldsymbol{c}^{\prime}$ and $\boldsymbol{i}^{\prime}$ are no primary and wild-type tissue controls, respectively. Scale bars, $100 \mu \mathrm{m}$. (present in Pfp and CC axons) and Tag-1 (present mainly in CC fibers) supported the expression of ephrinB1 in both Pfp and CC fibers (merged yellow) (Fig. 2e,f). This expression is maintained through E17, the period at which many CC fibers have crossed the midline and extended into the contralateral hemisphere (Rash and Richards, 2001).

EphrinB2 expression was detected using a $\beta$-gal enzymatic reaction on ephrinB2 ${ }^{\text {lac } Z}$ knock-in mouse tissue (Dravis et al., 2004), in which the intracellular domain of ephrinB2 was replaced with a $\beta$-gal molecule. At E15, the ephrinB2 fusion protein was expressed in tissues that correspond to various cortical layers, subventricular zone, Ig, GW, and the region of CC and Pfp fiber growth (Fig. 2g,h). At E17, ephrinB2 fusion protein was highly expressed in CC fibers and unique regions just ventral to the anterior horn of lateral ventricles (Fig. 2i). Unlike other B-class ephrins, ephrinB2 was not found in the septal nuclei but was maintained in lateral forebrain regions throughout development. Controls show no $\beta$-gal reactivity in wild-type CD1 mice (Fig. $\left.2 i^{\prime}\right)$.

EphrinB3 expression was detected using a $\beta$-gal enzymatic reaction on ephrinB3 ${ }^{\text {lac } Z}$ knock-in mouse tissue (Yokoyama et al., 2001) and showed a similar profile to ephrinB1 in that it was also found in the septum, lateral migratory pathway, Ig, GW, and Pfp between time points E15 and E18 (Fig. $2 j-n$ ). Colabeling using anti- $\beta$-gal against the ephrinB3 fusion protein and anti-GFAP confirmed expression in the Ig at E15 (Fig. 2l). EphrinB3 expression was mainly detected in the Pfp during all developmental time points but little to no expression was observed in the region of CC fiber growth. At the midline, ephrinB3 is expressed both dorsal and ventral to the CC, forming a "channel" through which callosal fibers migrate (Fig. $2 m, n$ ).

\section{Expression of Eph receptors in the developing forebrain}

The expression of Eph receptors was localized to callosal fibers during the period of midline pathfinding in the developing WT forebrain. At E15, EphB1, EphB2, EphB3, and EphA4 receptors are all expressed in the $\mathrm{CC}$ fibers before midline crossing (Fig. 3). Both EphB1 and EphB3 receptor expression as determined by antibody labeling were primarily present in callosal fibers beginning at E15 (Fig. $3 a, b$ ) and continuing through E17 (data not shown). EphB2 expression was evaluated using EphB2 lac ${ }^{\text {mice }}$ (Henkemeyer et al., 1996), and this fusion protein was present in superficial cortical layers, callosal fibers at E15-E17, as well as previously unreported areas corresponding to the GW and processes extending from subventricular zone (Fig. $3 c-f$ ). Like EphB2, EphA4 receptor was detected in the GW, Ig, and callosal fibers at E15 (Fig. $3 g$ ) and colabeled with the axonal marker GAP-43 in callosal fibers at E16 (Fig. 3i) and the glial marker GFAP at E16 and E17 (Fig. $3 j-l$ ). In addition, EphA4 was expressed in the striatum and the entire subventricular region (Fig. $3 g$ ). Immunoreactivity was not observed in their respective knock-out tissues (Fig. 3m-o).

\section{Genetic analysis of callosal defects in ephrinB3 and Eph receptor knock-out mice}

The data shown above indicates that B-class ephrins and their Eph receptors are expressed in both callosal fibers and guidepost regions at the period of midline pathfinding. To examine how ephrins and Eph receptors may influence midline guidance in the $\mathrm{CC}$, we examined the postnatal (P1) morphology of the CC in various single and double mutant mice compared with WT littermates (Fig. 4). CC defects were classified into the following two groups as defined by gross morphological appearance: (1) 
any visible defect in development of the $\mathrm{CC}$ and fewer $\beta$-tubulinIII-positive fibers at the midline (or hypoplasia) compared with WT mice, which included both mild and severe phenotypes (Fig. 4b) and (2) mice that had a severe agenesis of the CC (ACC) and visible Probst's bundle formations (Fig. 4c). First, we evaluated the genetic propensity for CC deformities strictly associated with outbred CD1 mouse strain and found no observable defects. We then examined ephrinB3 ${ }^{K O}$ mice, because this ephrin is expressed in forebrain guideposts and it may be a key regulator of midline guidance for Eph receptor-expressing CC axons. We found that $84 \%$ of ephrinB3 ${ }^{K O}$ mice exhibited some form of CC hypoplasia, whereas $64 \%$ had a severe ACC phenotype with Probst's bundles. Histological analysis was confirmed using the axonal specific antibody $\beta$-tubulinIII, which showed the majority of callosal fibers stalling at the midline (data not shown). CC defects were not observed in ephrinB3 $3^{\text {lac } Z}$ mice, which retain the ability to activate Eph receptors, suggesting that Eph receptor forward signaling is important for CC development. $E p h B 1^{K O}, E p h B 2^{K O}, E p h B 3^{K O}$, and EphA4 ${ }^{K O}$ mice were then evaluated; only $E p h B 1^{K O}(87 \%)$ and EphB2 ${ }^{K O}(61 \%)$ showed CC defects with 43 and 13\% having severe ACC defects, respectively. $E p h B 3^{K O}$ and $E p h A 4^{K O}$ mice did not show observable CC defects in Nissl-stained sections, and quantitation of the CC thickness at the midline in EphB3 ${ }^{K O}(238 \pm 12$ $\mu \mathrm{m} ; n=17)$ and EphA4 ${ }^{K O}(204 \pm 12 \mu \mathrm{m}$; $n=5)$ revealed no significant difference compared with WT $(276 \pm 10 \mu \mathrm{m} ; n=$ 15) mice. Interestingly, EphB2 $2^{\text {lac } Z}$ mice did not have CC defects (ACC or hypoplasia) or differences in CC thickness (251 \pm $11 \mu \mathrm{m} ; n=9$ ) compared with WT, suggesting that EphB2-mediated forward signaling is not critical for CC midline guidance. This may reflect an important requirement for ephrinB reverse signaling in CC axons.

To evaluate genetic interactions, we examined multiple combinations of Eph receptor double mutant mice. When $E p h B 1^{K O}$ was crossed with either $E p h B 2^{K O}$ or $E p h B 3^{K O}$ mice (i.e., $\left.E p h B 1^{K O} / E p h B 2^{K O}, E p h B 1^{K O} / E p h B 3^{K O}\right)$, there was no gross observable difference in phenotypic penetrance compared with EphB1 deficiencies alone. This suggests that EphB2 or EphB3 may not provide compensatory functions in the absence of EphB1. Examination of EphB2 $2^{K O} / E p h B 3^{K O}$ mice showed $100 \%$ penetrance, supporting a compensatory role for these two receptors and a function for EphB3 in CC midline guidance. However, evaluation of EphB2 lacZ/ $E p h B 3^{K O}$ mice did not reveal a similar phenotype, although these mice are deficient in both EphB2 and EphB3 signaling. This supports a ligand-like role for EphB2 in regional guideposts, where the abtively. Scale bars, $100 \mu \mathrm{m}$.
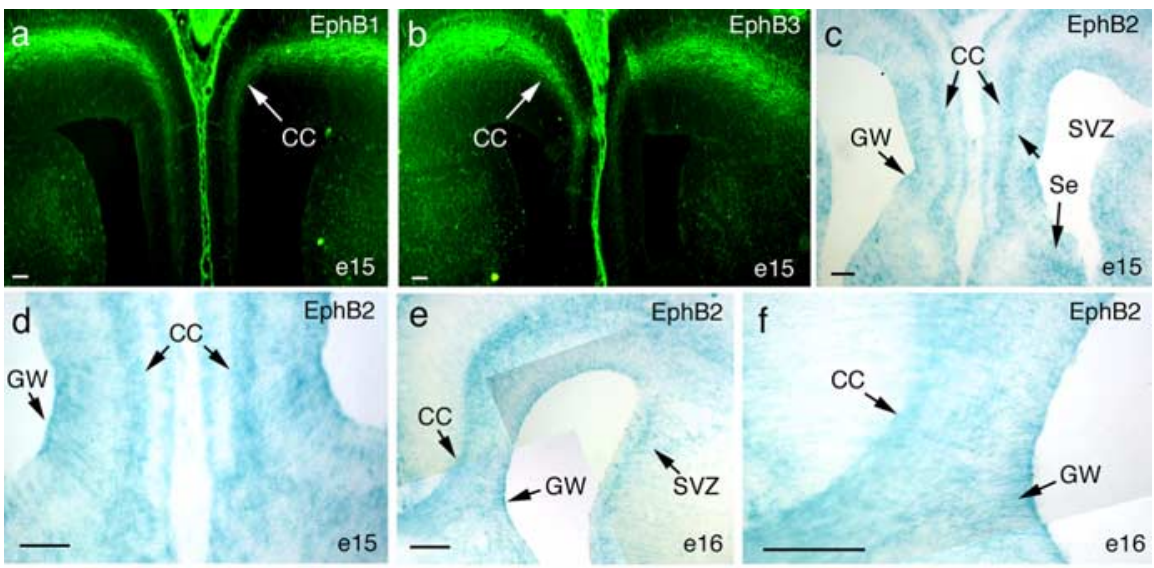

EphB2

$f$

EphB2
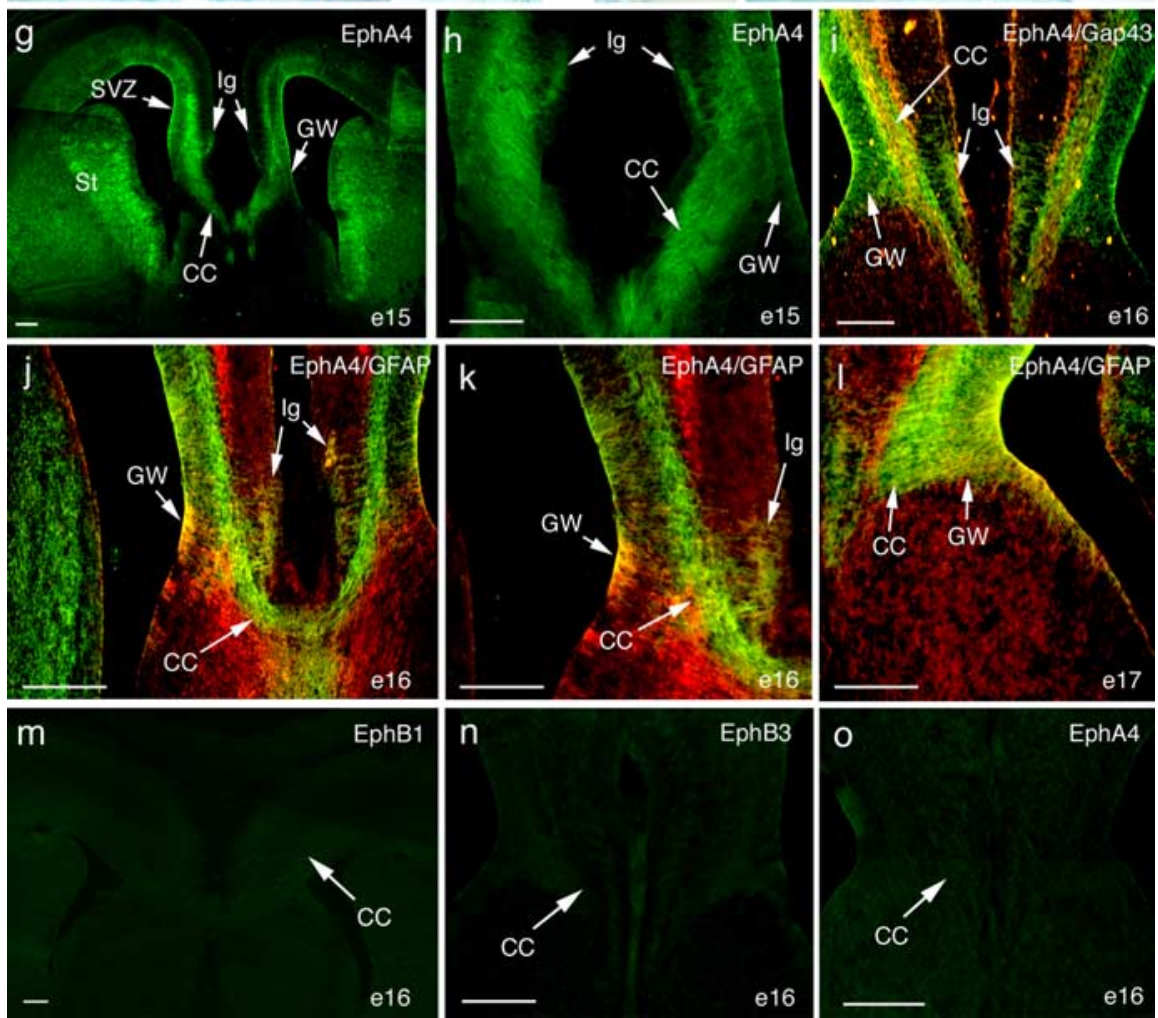

Figure 3. Eph receptors are expressed in the developing forebrain. EphB1 (a) and EphB3 $(\boldsymbol{b})$ are expressed specifically in the regions of the CC. EphB2 expression was visualized by examining $\beta$-gal expression in the EphB2 ${ }^{\text {lacZ }}$ mice. c, e, At E15 and E16, EphB2 ${ }^{\text {lacZ }}$ expression was detected in areas corresponding to $\mathrm{GW}, \mathrm{CC}$, septum (Se), and regions of the subventricular zone (SVZ).d, $\boldsymbol{f}$, High-magnification images of EphB2 expression in the GW, CC, and SVZ regions. $\boldsymbol{g}$, EphA4 was expressed in the regions of the CC, GW, Ig, striatum (St), and SVZ at E15. $\boldsymbol{h}$, High-magnification image of EphA4 expression at the midline in the CC, GW, and Ig. $\boldsymbol{i}_{\text {, }}$ EphA4 (green) and GAP-43 (red) are coexpressed in the (C but not in the GW or Ig at E16. $j-I$, EphA4 (green) colabels with GFAP (red) in the GW and Ig but not the CC atE16 and E17.I, High-magnification image of EphA4 (green) and GFAP (red) in the GW. $\boldsymbol{m}$ - 0 represent control anti-EphB1, anti-EphB3, and anti-EphA4 immunoreactivity on $E p h B 1^{K O}{ }^{E} E p h B 3^{K O}$, and EphA4 ${ }^{K O}$ tissues, respec-

sence of EphB2 would result in CC deficits mediated by a reduction in ephrinB reverse signaling in CC axons. Like EphB2, EphA4 receptors are also expressed in regional guideposts. However, unlike EphB2, EphA4 has not been shown to bind ephrinB1 or ephrinB2 (Blits-Huizinga et al., 2004). Examination of EphA4 single and double knock-out mice did not reveal a function for this receptor in CC midline crossing, which was confirmed by assessing CC thickness where no differences were observed between WT, EphA4 ${ }^{K O}$, and $E p h B 3^{K O} / E p h A 4^{K O}$ mice (data not shown). Interestingly, examination of EphB1 ${ }^{K O} / E p h A 4^{K O}$ mice revealed a significant decrease in penetrance compared with $E p h B 1^{K O}$ mice, although it remains to be 


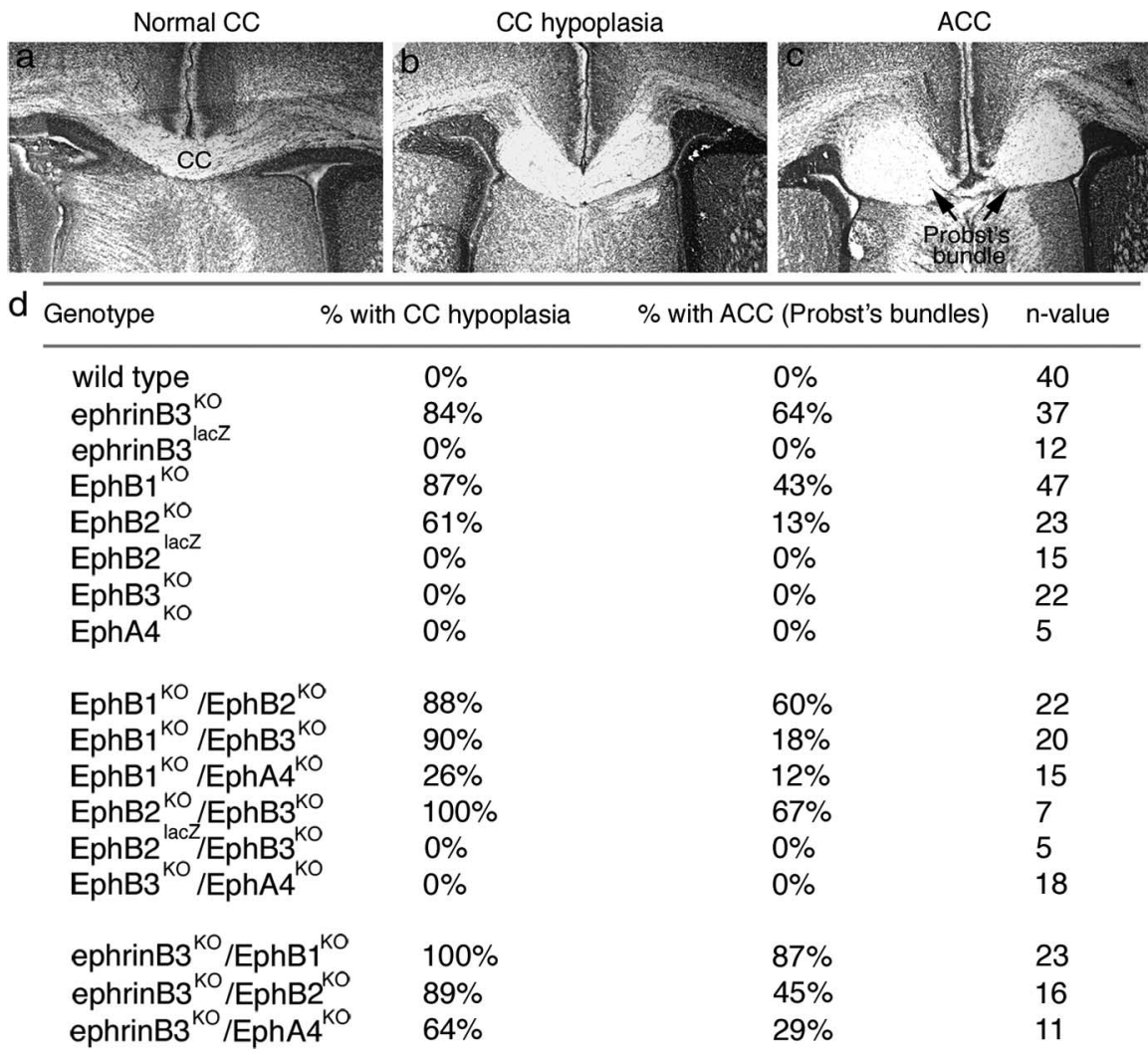

Figure 4. Frequency of CC Probst's bundle and hypoplasia formation in single and double knock-out ephrin/Eph receptor mice. $\boldsymbol{a}$, Representative Nissl-stained coronal section of a normal CC phenotype. $\boldsymbol{b}$, Nissl-stained section showing a representative CC hypoplasia phenotype from knock-out tissue. c, Representative Nissl-stained section exemplifies complete ACC with $>90 \%$ of axons not crossing the midline and the formation of Probst's bundles. $\boldsymbol{d}$, Frequencies of $C \mathrm{C}$ hypoplasia or ACC in single and combination mutant mice at P1 compared with WT CC phenotypes.

determined why the absence of EphA4 results in a reduction in hypoplasia.

We observed ephrinB3 expression in regional guideposts and Pfp fibers but little to no expression in CC fibers. Mice deficient in both ephrinB3 and EphB1 revealed 100\% penetrance in CC defects. The ephrinB3 ${ }^{K O} / E p h B 2^{K O}$ mice were not significantly different from ephrinB3 ${ }^{K O}$ mice alone, whereas ephrinB3 ${ }^{K O}$ / EphA4 ${ }^{K O}$ mice showed a reduction in penetrance. This further supports a role for EphA4 in CC development, although it is unclear what the role may reflect.

\section{Abnormal axon trajectories of callosal fibers in ephrinB3 and EphB1 mutant mice}

Our studies demonstrated that ephrinB3 and EphB1 are important mediators of CC midline crossing. We therefore chose to examine the trajectory of aberrant callosal fibers in ephrinB ${ }^{K O}$ and EphB1 ${ }^{K O}$ mice using lipophilic dye tracers, DiI and DiO (Fig. 5). In neonatal WT mice, GFAP-positive glial guideposts are still present, although the cortical callosal axons have already projected to the contralateral cortex (Fig. $5 a, b$ ). In ephrinB ${ }^{K O}$ mice, CC fibers stall ventrolateral to the region of midline crossing and form Probst's bundles (Fig. $5 c, d$ ). Interestingly, GFAP-expressing glial cells were found directly adjacent to and in the path of growing callosal fibers in ephrinB ${ }^{K O}$ mice with Probst's bundle formations. It is unclear whether these glial cells in the CC pathway originate from known GFAP-expressing regions, such as the GW, $\mathrm{Ig}$, and/or mzg, or from other regions in the knock-out mice. We used confocal microscopy to examine whether the swirling groups of axons that make up the Probst's bundles contact the glial cells that are adjacent to the Probst's bundles. Although the majority of the axonal surfaces were not in contact with glial cells, we did observe some regions of axon-glial contact (Fig. $5 e-g$ ), demonstrating the occurrence of axon-glial interactions (Fig. $5 g$, arrowheads).

To evaluate whether the glial cells that reside within the Probst's bundle reflect a radial glial lineage, we immunostained ephrinB3 ${ }^{K O}$ tissue with anti-RC-1 and anti-RC-2 antibodies (Fig. 5h-m). WT mice show RC-1 expression in the GW, Ig, $\mathrm{mzg}$, and $\mathrm{dLv}$ but not in the region of the CC fiber tract (Fig. 5h), whereas RC-2 expression was specific to the GW and $\mathrm{dLv}$ regions (Fig. 5i). Examination of RC-1 (Fig. 5j,k) and RC-2 (Fig. 5l,m) in ephrinB3 ${ }^{\mathrm{KO}}$ mice showed RC-1- and RC2-positive glial cells within the region of Probst's bundle formation. In addition, RC-2 was highly expressed in radial glial cells surrounding the lateral ventricle and GW regions, and radial glia processes can be observed surrounding the Probst's bundle (Fig. 5l). Similar Probst's bundle formations and glial migratory patterns were observed in EphB1 ${ }^{K O}$ mice (Fig. 6) but not ephrinB3 lacZ mice (data not shown). These findings demonstrate that cells that contain both glial and radial glial markers reside within the Probst's bundle and may participate in its formation.

To determine whether Pfp fibers were also rerouted or if Probst's bundles also included Pfp axons, we immunostained neonatal ephrinB $3^{K O}$ and EphB1 ${ }^{K O}$ forebrain tissue with anti-NF antibodies (which preferentially labels Pfp fibers) and anti-GFAP (Fig. 6). Similar results were observed in both ephrinB3 and EphB1 mutant mice, in which Pfp axons projected to and through the Probst's bundles, demonstrating that Pfp axons are also a component of the Probst's bundles. However, unlike CC axons, Pfp axons seem not to terminate in the Probst's bundle formation, although it is unclear whether these axons represent DBMS or cortical projecting neurons (Fig. 6c). These data suggest that complete ACC (associated with Probst's bundle formation) may result from developmental alterations in glial cell migration and include axons from both the CC and Pfp.

\section{EphB1 receptors regulate cortical axon outgrowth}

To determine whether the mutant cortical neurons are more or less responsive to glial wedge cells than WT cortical neurons, we examined the ability of cortical neurons to extend their axons in the presence and absence of EphB1 receptors. Dissociated E17 cortical neurons were grown for $3 \mathrm{~d}$ on either cortical or GW glial feeder layers, and their axons were visualized through expression of a transfected enhanced GFP (eGFP) marker (Fig. 7a). In the first $3 \mathrm{~d}$, cortical neurons extend their axons and were identified by having a growth cone and immunolabeling with anti-Tau-1 antibodies. We also identified that the E17 glial feeder layers contained a mixture of GFAP- and RC-2-expressing glial cells similar to the markers expressed in the GW in vivo (Fig. $7 b, c$ ), whereas 

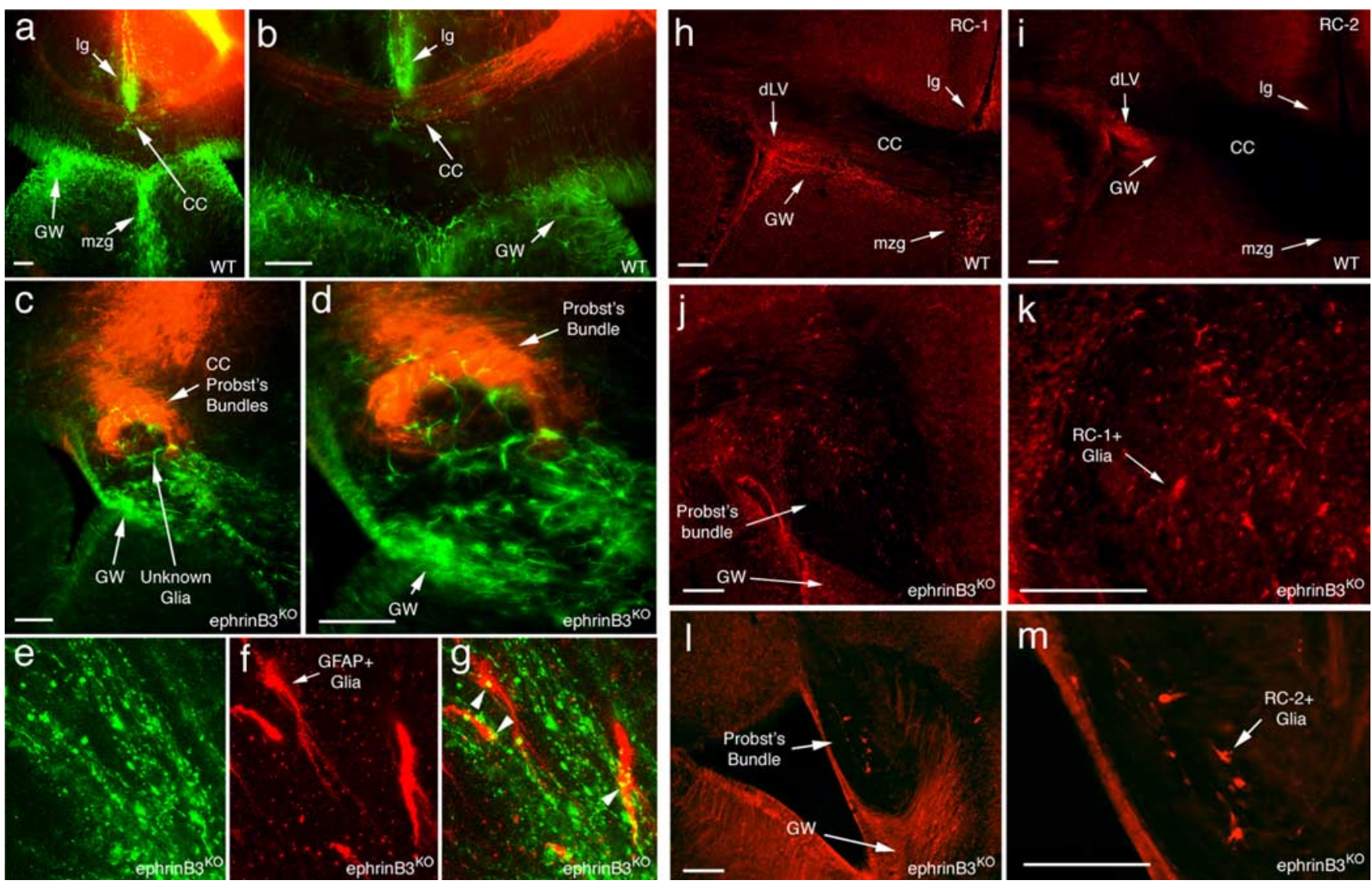

Figure 5. Pathfinding defects in the $C\left(\right.$ of ephrinB3 ${ }^{K O} \mathrm{P} 1$ mice results in aberrant glial cells localized to Probst's bundles. $\boldsymbol{a}$, Dil tracing of CC fibers (red) in WT tissue colabeled with GFAP (green) shows crossing of callosal fibers in the developing forebrain. $\boldsymbol{b}$, High-magnification image of Dil tracing shows callosal fibers (red) avoiding the GW and lg in WT mice. c, Dil tracing of CC fibers (red) in ephrinB $3^{K O}$ mice colabeled with GFAP (green)-expressing cells in the pathway of CC fibers. $\boldsymbol{d}$, High-magnification image of CC fibers (red) in ephrinB3 ${ }^{K O}$ mice shows close association of GFAP (green)-expressing glial cells. Confocal images of Di0-labeled CC axons ( $\boldsymbol{e}$, green) and GFAP-expressing glia $(\boldsymbol{f}$, red) show regions of axon-cell contact (yellow, arrowhead) $(\boldsymbol{g})$. Expression of the radial glia markers RC-1 (h) and RC-2 (i) shows normal expression in the guideposts in WT mice. Localization of RC-1- $(\boldsymbol{j})$ and RC-2-(I) positive cells in the region of Probst's bundle formation in ephrinB3 ${ }^{K O}$ tissues is shown. High-magnification images of RC-1- $(\boldsymbol{k})$ and RC-2-(m) positive radial glial cells in Probst's bundles are shown. Scale bars, $100 \mu \mathrm{m}$.

the cortical glial feeder layer contained only GFAP-expressing glial cells and not RC-2 glia (data not shown). When WT cortical neurons were grown on WT cortical glia, we observed an average axon length of $222 \pm 13 \mu \mathrm{m}$ after 3 d growth (Fig. $7 d$ ). There was a significant reduction in axon length $(146 \pm 8 \mu \mathrm{m})$ when cortical neurons were grown on GW feeder cells, supporting the growth suppressive nature of the GW cells as shown previously (Shu and Richards, 2001). Because EphB1 receptors are expressed on CC axons and not midline guidepost glia during forebrain development, we evaluated the ability of EphB1 ${ }^{K O}$ cortical neurons to grow on WT cortical and WT-GW feeder layers. We observed a similar effect of the GW on EphB1 ${ }^{K O}$ neurons, where an average axon length on cortical glia was $225 \pm 12 \mu \mathrm{m}$ and average axon length on GW glia was $103 \pm 5 \mu \mathrm{m}$. Comparison of WT and EphB1 ${ }^{K O}$ cortical axon growth on WT cortical glial feeder cells showed no significant difference between WT cortical neurons $(222 \pm 13 \mu \mathrm{m})$ and $E p h B 1^{K O}$ cortical neurons $(225 \pm 12$ $\mu \mathrm{m})$, demonstrating that the absence of EphB1 does not significantly affect axon growth ability in this context. However, comparison of the WT and EphB1 ${ }^{K O}$ cortical axon growth on WT glial wedge feeder cells showed attenuation in EphB1 ${ }^{K O}$ axon growth $(103 \pm 5 \mu \mathrm{m})$ compared with WT cortical axon growth $(146 \pm 8 \mu \mathrm{m})$. These findings suggest that cortical neurons are either less sensitive to growth promoting signals or have more responsiveness to growth inhibiting signals when EphB1 is absent. These findings support the observed reductions in CC ax- onal growth and Probst's bundle formation associated with the EphB1 ${ }^{\mathrm{KO}}$ mice.

To determine whether the reduced neurite outgrowth associated with the absence of EphB1 receptor were through direct ephrin/Eph interactions or indirect mechanisms, we examined the ability of wild-type and $E p h B 1^{K O}$ cortical neurons to grow on culture dishes coated with poly-D-lysine and $6.0 \mu \mathrm{g} / \mathrm{ml}$ ephrinB1Fc, ephrinB2-Fc, ephrinB3-Fc, or Fc only (Fig. 7e). We observed enhanced neurite outgrowth of wild-type cortical neurons grown on ephrinB1-Fc $(151.9 \pm 10.9 \mu \mathrm{m})$ and ephrinB2-Fc $(154.9 \pm$ $19.9 \mu \mathrm{m})$ compared with Fc-only $(60.7 \pm 4.7 \mu \mathrm{m})$ and ephrinB3-Fc $(67.7 \pm 4.8 \mu \mathrm{m})$ controls. Similar findings were observed when ephrinB-Fc molecules were plated at concentrations of $0.6 \mu \mathrm{g} / \mathrm{ml}$ (data not shown). These findings support a growth promoting function for Eph receptor interactions with ephrinB1 and ephrinB2 but not ephrinB3 in developing cortical neurons, which are supported by binding studies showing that EphB1 receptor binds ephrinB1 and ephrinB2 but not ephrinB3 (Davis et al., 1994; Cerretti et al., 1995; Brambilla et al., 1996; Gale et al., 1996a,b; Bergemann et al., 1998). Interestingly, in the absence of EphB1, cortical neurite outgrowth was not significantly increased in the presence of any ephrinB-Fc molecules compared with Fc only. These findings demonstrate that ephrinB1 and ephrinB2 mediate growth-promoting functions in cortical neurons through direct interactions with EphB1 receptors. 

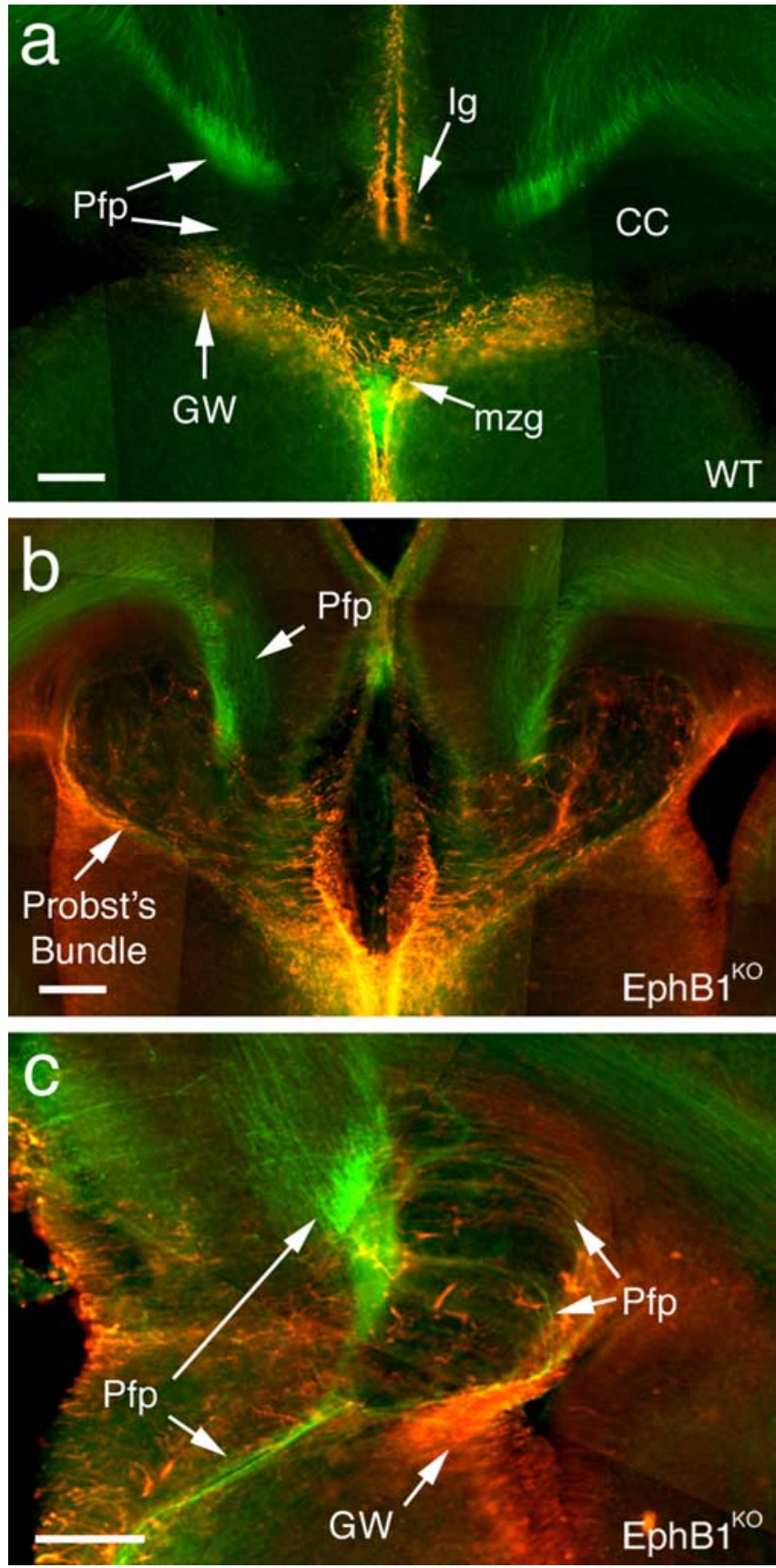

Figure 6. Probst's bundles include Pfp fibers in $E p h B 7^{K O}$ mice. $\boldsymbol{a}$, Neurofilament- $145 \mathrm{kDa}$ expressing (green) Pfp fibers colabeled with GFAP-expressing (red) guideposts (including GW, Ig, and mzg) in WT mice. $\boldsymbol{b}$, Neurofilament-expressing (green) Pfp fibers colabeled with GFAP expressing (red) guideposts (including GW, $\mathrm{lg}$, and $\mathrm{mzg}$ ) in $\mathrm{EphB1}{ }^{\mathrm{K} 0}$ mice. c, Highmagnification image showing NF-labeled Pfp axons extending through and around the Probst's bundle. Scale bars, $100 \mu \mathrm{m}$.

\section{Discussion}

In this study, we have shown that B-class ephrins and their respective Eph receptors are expressed in CC axons and surrounding areas during the critical period of CC development (Fig. 8a) and play important roles in callosal midline guidance (Fig. $8 b$ ). The complementary expression of multiple ligands and receptors in callosal fibers or midline regions results in an extremely complex pattern of developmental events critical for proper axon guidance. Disruption of these molecules can lead to a varying degree of CC growth defects, ranging from mild hypoplasia to
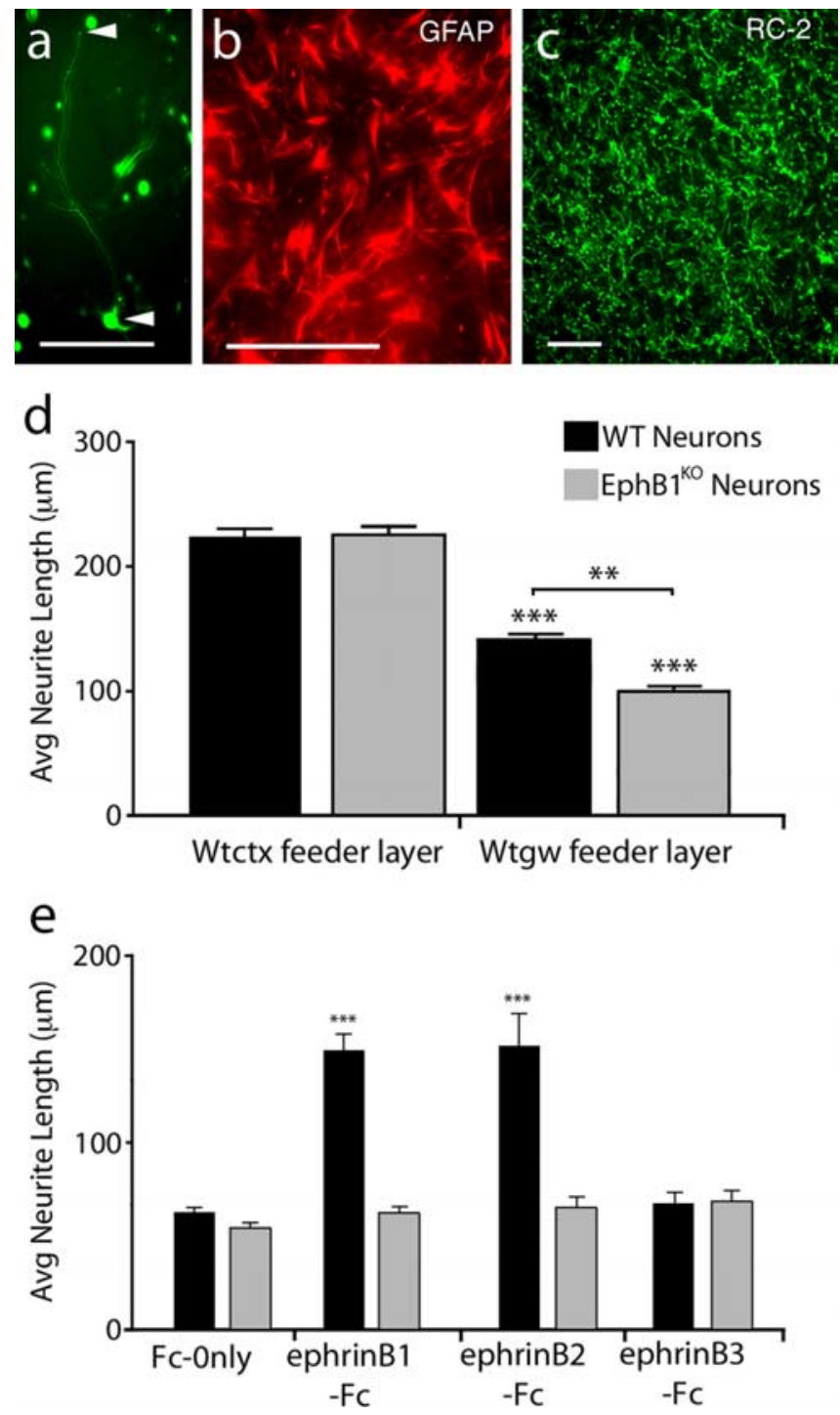

Figure 7. Cortical neurons have reduced neurite outgrowth when grown on GW feeder cells, where EphB1 interacts with ephrinBs to promote neurite outgrowth. Cortical neurons transfected with eGFP markers allow measurements of neurite length ( $\boldsymbol{a}$, between arrowheads) after $3 \mathrm{~d}$ of growth on GW feeder layers that express both GFAP (b) and RC-2 (c). Scale bars, $100 \mu \mathrm{m}$. $\boldsymbol{d}$, Average (Avg) neurite length of WT and EphB ${ }^{K O}$ cortical neurons are reduced when grown on WT glial wedge feeder (Wtgw) cells compared with WT cortical glial feeder (Wtctx) cells. WT and $E p h B 1^{K O}$ cortical neurons grown on Wtctx cells have similar mean neurite length, whereas $E p h B 1^{K O}$ cortical neurons grown on Wtgw cells shows significantly shorter neurites then WT cortical neurons grown on Wtgw cells. $\boldsymbol{e}$, WT cortical neurons grown on dishes coated with ephrinB1-Fc and ephrinB2-Fc showed significantly enhanced neurite outgrowth compared ephrinB3-Fc or Fc fragments, which are not observed in $E p h B 1^{K O}$ cortical neurons. Error bars indicate mean \pm SEM. ${ }^{* *} p<0.01 ;{ }^{* * *} p<0.001$.

complete agenesis and formation of Probst's bundles. The degree of penetrance in mutant animals may be associated with changes in residential glial formations in and around the growing CC tract, because we detected abnormal positioning of glia surround the axonal swirls that make up the Probst's bundles.

Our expression analysis indicates that ephrinB1 and ephrinB2 are located in the callosal fibers, whereas one of their binding partners EphB2 is located in the GW and Ig. We also observed that EphB1, EphB2, EphB3, and EphA4 are all present in callosal fibers, whereas their potential binding partners (i.e., ephrinB1, ephrinB2, and ephrinB3) are all expressed in midline guideposts. Based on these coordinated expression patterns, we have hypoth- 

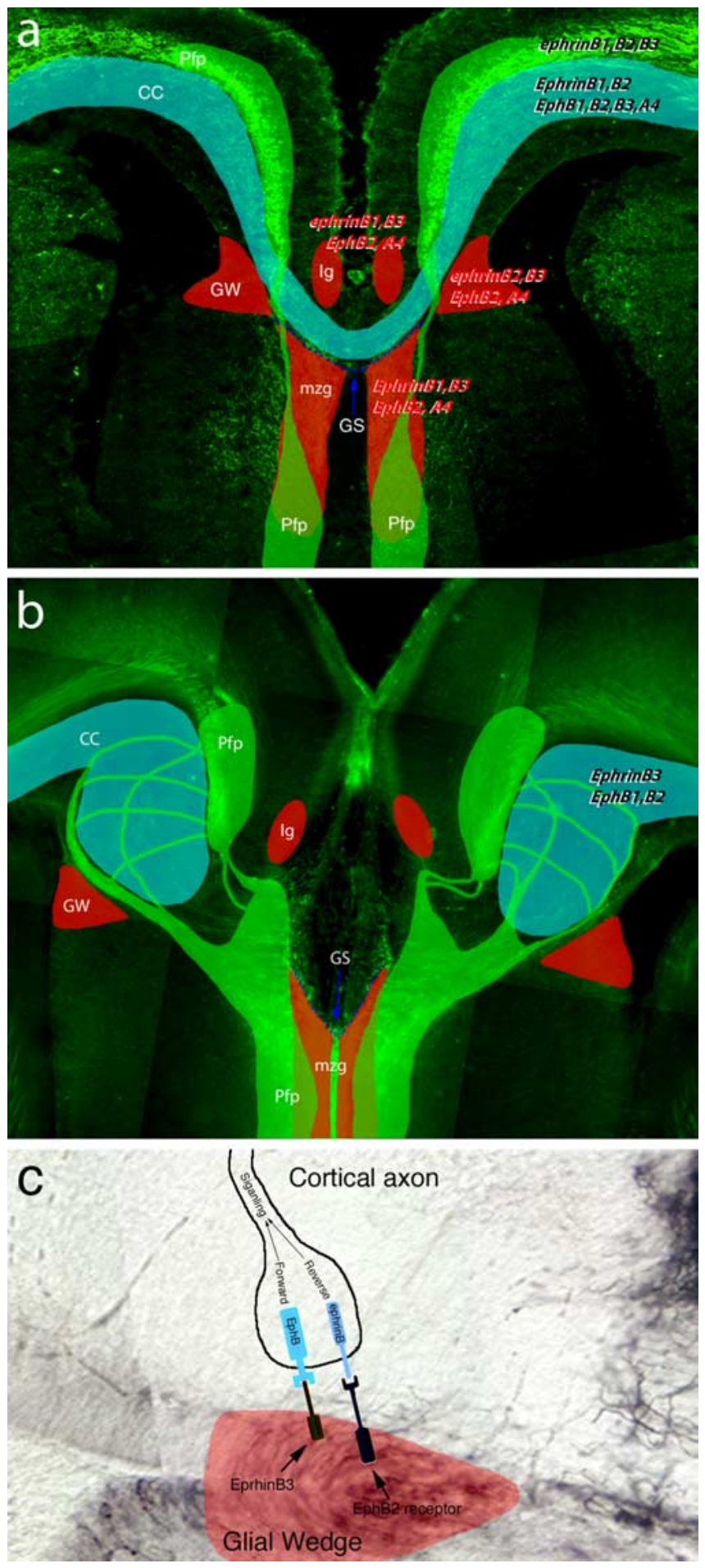

Figure 8. $\quad \boldsymbol{a}$, Summary of expression of B-class ephrins and Eph receptors superimposed with a schematic coronal cross section showing CC, Pfp, and midline guideposts [GW, Ig, glial sling (GS), and mzg] during development. $\boldsymbol{b}$, Schematic representation of CC and Pfp growth patterns in the ephrinB3 and EphB1 knock-out mice. c, Schematic representation of a cortical fiber interacting with the GW guidepost. Callosal axons contain both reverse and forward signaling mediated by ephrins and Eph receptors after interactions with either EphB2 or ephrinB3 in guideposts, respectively.

esized that interactions occur between Eph receptors present in callosal axons and ephrins in midline glia and vice versa (Fig. 8c). Although we cannot rule out the possibility that interactions might also occur between callosal fibers, thereby influencing the levels of axon fasciculation/defasciculation. These molecules have been shown to play a role in the defasciculation of hippocampal axons at the lateral septum and fasciculation of cortical axons in culture (Barinaga, 1995; Winslow et al., 1995; Chen et al., 2004). It is difficult to evaluate axon fasciculation of CC or Pfp axons with the formation of Probst's bundles; however, more detailed investigations of mutant mice may uncover an additional role for these molecules in either fasciculation or defasciculation.

In addition to investigating the temporal and spatial distribution of ephrins and Eph receptors, we also show that ephrinB3 and Eph receptors are critical for midline guidance of CC fibers using gene-targeted knock-out mice. Our analysis of ephrinB3 demonstrates that it is expressed in midline guideposts and is an important regulator of CC midline crossing. EphrinB3 ${ }^{K O}$ mice have significant defects in CC midline crossing that are not observed in the ephrinB $3^{\text {lac } Z}$ knock-in mice, suggesting that forward signaling through Eph receptor(s) is important. EphB2 and EphB3 receptors are all potential binding partners for ephrinB3 and have the possibility of mediating this forward signaling (Blits-Huizinga et al., 2004). Previous investigations have evaluated ephrinB3 ${ }^{K O}$ mice and report that $\sim 20 \%$ of knock-out mice have CC agenesis (Yokoyama et al., 2001). Our data support a more critical function for this ligand, whereas other tracts such as the anterior commissure and hippocampal commissure remained unaffected, as reported previously. Previous reports also indicate $E p h B 2^{K O}$ and EphB3 ${ }^{K O}$ are important in CC development and these receptors have overlapping functions during $C C$ development (Orioli et al., 1996). Our results support a much more complex set of genetic interactions during development and modify existing genetic data that explain the interaction between EphB2 and EphB3 receptors. We did not observe CC defects in single EphB3 ${ }^{K O}$ mice as shown previously (Orioli et al., 1996). In contrast, EphB2 ${ }^{K O}$ mice exhibited a higher frequency of CC defects, whereas EphB3 ${ }^{K O}$ mice had no observable defects in CC pathfinding compared with WT mice. We did confirm previous results showing that removal of both receptors dramatically increased the frequency of defects. One explanation for these conflicting results may be that our animals were analyzed in a pure CD1 background, whereas previous analyses were performed in a mixed 129/sv and C57BL/6J background. Neither strain has significant incidence of spontaneous CC agenesis, so an explanation for these conflicting results remains to be determined. The absence of midline defects in the EphB2 ${ }^{\text {lac } Z}$ knock-in mice suggests that EphB2 functions in a kinase-independent manner, which is in agreement with previous findings on the anterior commissure (Henkemeyer et al., 1996; Cowan et al., 2004). This would support a hypothesis that the expression of EphB2 in midline guidepost cells may be more critical for midline guidance than its expression in the CC axons. These findings imply that ephrinB1 and/or ephrinB2 signaling in callosal fibers may also be important for CC midline pathfinding and/or growth promoting decisions (unfortunately, ephrinB1 ${ }^{K O}$ and ephrinB2 ${ }^{K O}$ mutant mice were not available for CC analysis). Together, our data indicate that CC axons require both reverse and forward signaling to mediate midline guidance.

Combination mutants of EphB1 and either EphB2, EphB3, or EphA4 did not increase the frequencies of CC defects compared with single knock-out mice, whereas $E p h B 2^{K O} / E p h B 3^{K O}$ and ephrinB $3^{K O} / E p h B 1^{K O}$ mice did show compensatory mechanisms. Because ephrinB3 is expressed in guideposts and not CC fibers, we interpret these findings to reflect an absence in signaling from multiple Eph receptors (including EphB1) in CC fibers. 
The ephrinB3 $3^{K O} / E p h B 1^{K O}$ mutation results in complete penetrance with most animals having severe ACC. There was not a significant increase in CC defects observed in the ephrinB3 ${ }^{\mathrm{KO}}$ / $E p h B 2^{K O}$ mice, whereas ephrinB3 ${ }^{K O} / E p h A 4^{K O}$ mice exhibited a decrease in CC agenesis compared with ephrinB ${ }^{K O}$ mice alone. Together, these findings support a complex genetic interaction between multiple ephrins and Eph receptors in regulating CC midline guidance.

Previous studies have demonstrated that ephrinB3 interactions with Eph receptors are generally nonpermissive to growing cortical neurons (Dottori et al., 1998; Yokoyama et al., 2001; Kullander et al., 2003). This might suggest that cortical axons would grow through midline guideposts in mice lacking these molecules. However, we do not observe aberrant growth of cortical axons through midline guideposts but have actually found that cortical axons stalled and formed bundles before contacting midline guideposts. In addition, these axon bundles were surrounded by glial cells that may have migrated from other midline guideposts such as the GW, Ig, or mzg. These observations suggest that the aberrant migration of glial cells may participate in Probst's bundle formation by possibly forming a barrier to growing CC axons (Fig. 5c,d). Both contact-mediated (i.e., ephrins/ Eph receptors and $\mathrm{L} 1$ ) and secreted guidance factors (i.e., slits and netrins) have been implicated in regulating normal pathfinding of CC axons, so whether a barrier is formed by these molecules remains to be determined (Richards et al., 2004). Although it is unclear where these glial cells migrated from, it is clear that these glial cells do not normally reside in the CC tract in WT mice. We could speculate that ephrins or Eph receptors function to regulate glial cell migration and in the absence of ephrins these glial cells aberrantly migrate into the pathway of the growing $\mathrm{CC}$ fibers. However, ephrinB3 ${ }^{\text {lac } Z}$ and EphB2 ${ }^{\text {lac } Z}$ signaling mutants do not show aberrant glial migration, suggesting that this phenotype is not caused by the absence of ephrinB3 or EphB2 signaling in glial populations. Additional studies are needed to examine the role of ephrins and Eph receptors on glial cell migration and callosal fiber interactions with these guideposts.

To evaluate the function of Eph receptors in regulating cortical neuron growth, we examined cortical axon growth of $E p h B 1^{K O}$ neurons cocultured on glial feeder cells. This coculture system has the advantage of examining growth rates of individual neurons as they respond to growth-promoting/suppressive cues from either cortical or GW feeder layers. We found that in the absence of EphB1, cortical neurons do not result in enhanced growth, as would be expected if these receptors were transmitting growth restrictive cues. In fact, the opposite was observed where EphB1 ${ }^{K O}$ cortical neurons had reduced responsiveness, suggesting that EphB1 may mediate growth-promoting functions. These findings were further supported by enhanced growth of EphB1expressing cortical neurons when in contact with either ephrinB1 or ephrinB2, demonstrating a direct role for EphB1 in mediating growth-promoting functions. These experiments confirmed the growth promoting role for ephrinB1 in young rat cortical neurons, as described previously (Zhou et al., 2001). Hu and colleagues (2003) recently showed that purified callosal neurons extend longer neurites when grown on ephrinA5-transfected cells lines. Furthermore, this same study showed that in the absence of EphA5 kinase activity, CC fibers fail to enter the CC tract and extend through appropriate midline regions, resulting in a hypoplasia phenotype (Hu et al., 2003). One possible explanation for the apparent growth promoting function is the possibility that Eph receptors may interact with other families of growth regulating molecules. It is unclear what specific molecule(s) may be mediating this altered sensitivity; however, both the slit and netrin families are strong possibilities because both in vitro and in vivo data have implicated these molecules in CC development through either attractive or repulsive functions (Stein and Tessier-Lavigne, 2001; Shu et al., 2003a; Richards et al., 2004). A second possible explanation of Probst's bundle formation is that ephrinBs may regulate growth-promoting functions through Eph forward signaling, suggesting that in the absence of ephrinB1, ephrinB2, or EphB1, CC axons have a reduced ability to extend at choice points.

In humans, ACC is thought to have autosomal-dominant, autosomal-recessive, and X-linked forms with $>20$ autosomal malformation syndromes, including FG syndrome, MillerDieker syndrome, Aicardi syndrome, Donnai-Barrow syndrome, Joubert syndrome, Kallmann syndrome, Andermann syndrome, and agenesis of the corpus callosum with peripheral neuropathy. Although many of these disorders are mapped to specific chromosomal regions, studies are only beginning to identify the genetic basis for these diseases. One example is FG syndrome, which has a gene map locus of Xq12-q21.31. Patients with FG syndrome are affected with mental retardation, disproportionately large head, hypospadia, cleft lip/palate, cogenital hypotonia, and ACC (Opitz et al., 1988; Dessay et al., 2002). Interestingly, ephrinB1 is localized to this same locus (Xq12-q13.1), although it is unclear whether ephrinB1 is responsible for the ACC phenotype. One neurological syndrome known to have $\mathrm{CC}$ defects and result from ephrinB1 missense mutations is craniofrontonasal syndrome (CFNS) (Dessay et al., 2002; Wieland et al., 2004). Like FG syndrome, CFNS is also characterized by skeletal abnormalities and midline abnormalities such as cleft lip/palate and CC hypoplasia. We are just beginning to unravel the role of ephrins and Eph receptors in human diseases.

In summary, our results introduce a new complexity to the role of B-class ephrins and Eph receptors in the development of the CC. Multiple receptors and ligands are dynamically expressed in both the developing CC and known midline guideposts. We have revealed novel genetic interactions that seem to be critical for growth and guidance of callosal fibers in the mouse forebrain. Furthermore, our data show that one mechanism by which these receptors and ligands function during development is to restrict glial growth and regulate the axons responsiveness to growth and guidance cues. These results expand previous knowledge and reveal that the establishment of complex neural circuitry is regulated by equally complex molecular and genetic events.

\section{References}

Barinaga M (1995) Receptors find work as guides. Science 269:1668-1670. Bergemann AD, Zhang L, Chiang MK, Brambilla R, Klein R, Flanagan JG (1998) Ephrin-B3, a ligand for the receptor EphB3, expressed at the midline of the developing neural tube. Oncogene 16:471-480.

Birgbauer E, Oster SF, Severin CG, Sretavan DW (2001) Retinal axon growth cones respond to EphB extracellular domains as inhibitory axon guidance cues. Development 128:3041-3048.

Blits-Huizinga CT, Nelersa CM, Malhotra A, Liebl DJ (2004) Ephrins and their receptors: binding versus biology. IUBMB Life 56:257-265.

Brambilla R, Bruckner K, Orioli D, Bergemann AD, Flanagan JG, Klein R (1996) Similarities and differences in the way transmembrane-type ligands interact with the Elk subclass of Eph receptors. Mol Cell Neurosci 8:199-209.

Cerretti DP, Vanden Bos T, Nelson N, Kozlosky CJ, Reddy P, Maraskovsky E, Park LS, Lyman SD, Copeland NG, Gilbert DJ, Jenkins NA, Fletcher FA (1995) Isolation of LERK-5: a ligand of the eph-related receptor tyrosine kinases. Mol Immunol 32:1197-1205.

Chen ZY, Sun C, Reuhl K, Bergemann A, Henkemeyer M, Zhou R (2004) Abnormal hippocampal axon bundling in EphB receptor mutant mice. J Neurosci 24:2366-2374. 
Cowan CA, Yokoyama N, Saxena A, Chumley MJ, Silvany RE, Baker LA, Srivastava D, Henkemeyer M (2004) Ephrin-B2 reverse signaling is required for axon pathfinding and cardiac valve formation but not early vascular development. Dev Biol 271:263-271.

Davis S, Gale NW, Aldrich TH, Maisonpierre PC, Lhotak V, Pawson T, Goldfarb M, Yancopoulos GD (1994) Ligands for EPH-related receptor tyrosine kinases that require membrane attachment or clustering for activity. Science 266:816-819.

Dessay S, Moizard MP, Gilardi JL, Opitz JM, Middleton-Price H, Pembrey M, Moraine C, Briault S (2002) FG syndrome: linkage analysis in two families supporting a new gene localization at Xp22.3 [FGS3]. Am J Med Genet 112:6-11.

Dickson BJ (2002) Molecular mechanisms of axon guidance. Science 298:1959-1964.

Dottori M, Hartley L, Galea M, Paxinos G, Polizzotto M, Kilpatrick T, Bartlett PF, Murphy M, Kontgen F, Boyd AW (1998) EphA4 (Sek1) receptor tyrosine kinase is required for the development of the corticospinal tract. Proc Natl Acad Sci USA 95:13248-13253.

Dravis C, Yokoyama N, Chumley MJ, Cowan CA, Silvany RE, Shay J, Baker LA, Henkemeyer M (2004) Bidirectional signaling mediated by ephrin-B2 and EphB2 controls urorectal development. Dev Biol 271:272-290.

Gale NW, Holland SJ, Valenzuela DM, Flenniken A, Pan L, Ryan TE, Henkemeyer M, Strebhardt K, Hirai H, Wilkinson DG, Pawson T, Davis S, Yancopoulos GD (1996a) Eph receptors and ligands comprise two major specificity subclasses and are reciprocally compartmentalized during embryogenesis. Neuron 17:9-19.

Gale NW, Flenniken A, Compton DC, Jenkins N, Copeland NG, Gilbert DJ, Davis S, Wilkinson DG, Yancopoulos GD (1996b) Elk-L3, a novel transmembrane ligand for the Eph family of receptor tyrosine kinases, expressed in embryonic floor plate, roof plate and hindbrain segments. Oncogene 13:1343-1352.

Helmbacher F, Schneider-Maunoury S, Topilko P, Tiret L, Charnay P (2000) Targeting of the EphA4 tyrosine kinase receptor affects dorsal/ventral pathfinding of limb motor axons. Development 127:3313-3324.

Henkemeyer M, Orioli D, Henderson JT, Saxton TM, Roder J, Pawson T, Klein R (1996) Nuk controls pathfinding of commissural axons in the mammalian central nervous system. Cell 86:35-46.

Hu Z, Yue X, Shi G, Yue Y, Crockett DP, Blair-Flynn J, Reuhl K, Tessarollo L, Zhou R (2003) Corpus callosum deficiency in transgenic mice expressing a truncated ephrin-A receptor. J Neurosci 23:10963-10970.

Huber AB, Kolodkin AL, Ginty DD, Cloutier JF (2003) Signaling at the growth cone: ligand-receptor complexes and the control of axon growth and guidance. Annu Rev Neurosci 26:509-563.

Kaprielian Z, Runko E, Imondi R (2001) Axon guidance at the midline choice point. Dev Dyn 221:154-181.

Klein R (2004) Eph/ephrin signaling in morphogenesis, neural development and plasticity. Curr Opin Cell Biol 16:580-589.

Kudo C, Ajioka I, Hirata Y, Nakajima K (2005) Expression profiles of EphA3 at both the RNA and protein level in the developing mammalian forebrain. J Comp Neurol 487:255-269.
Kullander K, Klein R (2002) Mechanisms and functions of Eph and ephrin signalling. Nat Rev Mol Cell Biol 3:475-486.

Kullander K, Butt SJ, Lebret JM, Lundfald L, Restrepo CE, Rydstrom A, Klein R, Kiehn O (2003) Role of EphA4 and EphrinB3 in local neuronal circuits that control walking. Science 299:1889-1892.

Opitz JM, Richieri-da Costa A, Aase JM, Benke PJ (1988) FG syndrome update 1988: note of 5 new patients and bibliography. Am J Med Genet 30:309-328.

Orioli D, Henkemeyer M, Lemke G, Klein R, Pawson T (1996) Sek4 and Nuk receptors cooperate in guidance of commissural axons and in palate formation. EMBO J 15:6035-6049.

Rash BG, Richards LJ (2001) A role for cingulate pioneering axons in the development of the corpus callosum. J Comp Neurol 434:147-157.

Richards LJ, Plachez C, Ren T (2004) Mechanisms regulating the development of the corpus callosum and its agenesis in mouse and human. Clin Genet 66:276-289.

Shu T, Richards LJ (2001) Cortical axon guidance by the glial wedge during the development of the corpus callosum. J Neurosci 21:2749-2758.

Shu T, Sundaresan V, McCarthy MM, Richards LJ (2003a) Slit2 guides both precrossing and postcrossing callosal axons at the midline in vivo. J Neurosci 23:8176-8184.

Shu T, Puche AC, Richards LJ (2003b) Development of midline glial populations at the corticoseptal boundary. J Neurobiol 57:81-94.

Silver J, Edwards MA, Levitt P (1993) Immunocytochemical demonstration of early appearing astroglial structures that form boundaries and pathways along axon tracts in the fetal brain. J Comp Neurol 328:415-436.

Stein E, Tessier-Lavigne M (2001) Hierarchical organization of guidance receptors: silencing of netrin attraction by slit through a Robo/DCC receptor complex. Science 291:1928-1938.

Tessier-Lavigne M, Goodman CS (1996) The molecular biology of axon guidance. Science 274:1123-1133.

Wieland I, Jakubiczka S, Muschke P, Cohen M, Thiele H, Gerlach KL, Adams RH, Wieacker P (2004) Mutations of the ephrin-B1 gene cause craniofrontonasal syndrome. Am J Hum Genet 74:1209-1215.

Wilkinson DG (2001) Multiple roles of EPH receptors and ephrins in neural development. Nat Rev Neurosci 2:155-164.

Williams SE, Mann F, Erskine L, Sakurai T, Wei S, Rossi DJ, Gale NW, Holt CE, Mason CA, Henkemeyer M (2003) Ephrin-B2 and EphB1 mediate retinal axon divergence at the optic chiasm. Neuron 39:919-935.

Winslow JW, Moran P, Valverde J, Shih A, Yuan JQ, Wong SC, Tsai SP, Goddard A, Henzel WJ, Hefti F, Beck KD, Caras IW (1995) Cloning of AL-1, a ligand for an Eph-related tyrosine kinase receptor involved in axon bundle formation. Neuron 14:973-981.

Yokoyama N, Romero MI, Cowan CA, Galvan P, Helmbacher F, Charnay P, Parada LF, Henkemeyer M (2001) Forward signaling mediated by ephrin-B3 prevents contralateral corticospinal axons from recrossing the spinal cord midline. Neuron 29:85-97.

Zhou X, Suh J, Cerretti DP, Zhou R, DiCicco-Bloom E (2001) Ephrins stimulate neurite outgrowth during early cortical neurogenesis. J Neurosci Res 66:1054-1063. 